\title{
CONTINUOUS DEVELOPMENT IS A GUARANTEE OF SUCCESS
}

\author{
Mykola Kulyk \\ National Aviation University, 1 Cosmonavta Komarova Ave., 103058 Ukraine, Kiev \\ E-mail:post@nau.edu.ua
}

Received 24 July 2008; accepted 14 August 2008

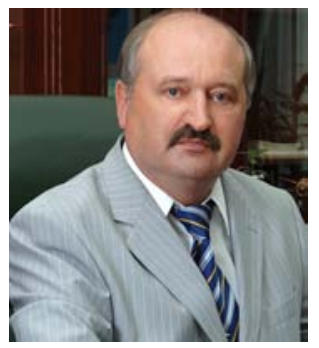

Mykola KULYK, Prof Dr Sci Eng

Education: Kiev Institute of Civil Aviation Engineers, 1976. 1993 - Doctor of Science (Engineering) Affiliations and functions: 1997 - head of the Air Engines Department.

Honours, awards: Honored figure of Science and Engineering of Ukraine, Winner of the State Price of Ukraine in the area of science and technology.

Present position: rector of National Aviation University, Ukraine.

Research interests: automatic systems of aircraft engines technical conditions.

Publlications: over 200 scientific papers.

The National Aviation University (NAU, Kiev, Ukraine), the diploma of which has been and remains indicative of quality and professional skills and is recognized as competitive in many countries, holds a special place among higher educational institutions of aviation throughout the world.

The university was founded in 1933 when the rapid development of domestic aircraft manufacture required an immense number of aviation specialists with higher education. About 150,000 specialists have been trained during the 75 years of its existence, and they work in more than 150 countries now. They are prominent scientists, educators, military officers, managers of airlines, and aviation personnel in various spheres of professional activities.

During the years of its existence, the university has changed its name few times: Kiev Aviation Institute (1933), Kiev Institute of the Civil Air Fleet (1947), Kiev Civil Aviation Engineers Institute (1965), Kiev International University of Civil Aviation (1994), and the National Aviation University (2000). The intention of the university staff to train high quality specialists, to educate dedicated, emphatic and creative individuals has been and still remains immutable.

Nowadays the National Aviation University is a student megapolis, which incorporates 17 academic institutes, 10 research and development institutes and centers, 20 faculties, 7 colleges, 3 lyceums, and a gymnasium. The total area of 14 university training buildings in Kiev is 140,000 square meters and more than 30,000 students get education on 75 specialties there.

The qualified staff, including 8 academics and correspondent members of National Academy of Sciences of Ukraine, 37 academics of different branches of academies of sciences, 208 doctors of science who are professors, and $840 \mathrm{PhDs}$ who are associate professors, provides high-quality specialists training together with active scientific work. Among the university staff there are 30 state laureates in the fields of science and engineering, 27 Honoured Scientists, 15 Honoured Educationalists, 3 Honoured and 18 Honorary Workers of the Transport Industry, Honoured Inventors; judges, economists, journalists and workers in the cultural sphere.

The university has a training aerodrome, a unique hangar for aircraft of different types and purposes, a signals training area, an aviation on-ground equipment training area, an aerodynamics centre, and a great and impressive scientific-technical library. The university campus consists of 11 dormitories, a Centre of Culture and Art, a sports complex, a recreational centre, a medical centre, and a health-centre At the National Aviation University, all conditions for fruitful and comfortable work, study and rest are created.

An individual approach to each young person, both at enrollment and during the process of studies, has become one of the important methods of improving the quality of the professional training of specialists at NAU. Considering the experience of leading establishments of higher education around the world, where the system of education is based on systematic individual search and selection, taking into account the inclinations, skills and talent of youth and paying 
great attention to the pre-university professional training of pupils. After enrollment, students are motivated for selfeducation and self-improvement by focusing on individual inclinations and skills. To achieve this purpose, individual planning is being used, in particular, studying optional subjects chosen by students as well as compulsory ones, studying simultaneously in two majors, changing majors (if required), etc.

Beginning with the fourth year of study, students of the university can take an additional major for getting the second speciality. For example, students of technic specialization can study air and space law, economics, finances.

Best students have an opportunity to study at the Innovative Technologies Institute while working on their master's degrees. The main purpose of this institute, which was founded at NAU at the order of the Ministry of Education and Science and National Academy of Science of Ukraine, is individual training of the most talented master's degree students for their further scientific-pedagogical or scientific activities. They study and practice according to their individual programmes at the academic institutes in small groups under the supervision of the leading scientists of the country. As a result, the path of future educators and scientists to the post-graduate department is shortened. Individuals able to grasp and develop new ideas are formed.

It is evident that such an approach creates brand new tasks, different from the traditional form of education, for university staff. The role of an educator as a source of information does not lessen, but becomes more important in the development of personal qualities and formation of a world outlook. An educator becomes not just a simple retransmitter of knowledge, but also an instructor, an advisor, and a mentor in the process of the individual independent work of students.

An essential component of the studying process is the scientific and research activity of students and educators at the university. The National Aviation University is one of the most powerful scientific centres in Ukraine. It consistently and diligently enlarges and extends its comprehensive scientific activity in accordance with the accepted conception of transformation from an educationally scientific establishment into a scientific-educational one.

University scientific activity is focused on developing scientific research work, creating branch and inter-branch centres, training the highest quality scientific personnel, participating in foreground state and international scientific programmes with the use of a full-scale computer information exchange network, etc. The complex of fundamental and socio-economic research of scientists at the university is connected with innovative information and nanotechnologies and the use of the capabilities of the aerospace industry.

University scientists pay much attention to the application of nanotechnologies in socio-technical systems and creation of means of telecommunication, use of nanosystems in informational technologies, and application of nanotechnologies in creating means for the detection of potentially dangerous objects, which has become one of the major directions in full-scale scientific research. A powerful, up-to-date, multi-vector research and development laboratory complex was created within the aviation research and development institute. Scientific laboratories of technical diagnostics and non-destructive methods of aviation equipment control, automation of technological processes in manufacturing, special psycho-physiological technologies and investigation of video system problems, applied television, etc. have been created and successfully operate.

Urgent directions of scientific search at the university are diagnostics and the safety of aircraft and their systems, in particular, determination of the condition of airborne power systems, development of systems on the basis of satellite technologies, diagnostics of composite materials by low-speed strike method, impedance diagnostics of composite materials, acoustic emission technical diagnostics, and diagnostics of dynamic performances.

Scientists of the university carry out fundamental research in the following areas: operation and air navigation support in aviation, air traffic management, avionics, information security, safety in aviation, ecology and environmental protection, management and economics, air and space law, etc. Essential attention is paid to systems of aircraft control and flight control of small unmanned aircraft.

An automated information system for planning and regulating air traffic was developed and implemented. The peculiarity of this system is the realization of the concept of artificial intelligence. A landing navigation complex was created by applying information technologies. The combination of information-calculating and information-measuring systems in the complex allowed aircraft dynamic performances to be taken into account, and that provides implementation of special category landing in extreme flight conditions.

DIK-01.0, a multichannel computer complex for special psycho-physiological research, was developed (Fig 1). The complex is used for solving problems connected with psycho-physiological provision of the Human-HardwareSociopsychological Environment system activity.

The Micron GAMA device was developed for testing surfaces with different material properties by means of measuring the physical and mechanical characteristics in micro and nanovolumes by applying methods of continuous indention and diamond indenter scanning (Fig 2). The recording of indentions and measurement results is done automatically. For small size samples and thin surfaces, it is the only way to evaluate the micro hardness, elasticity modulus, and other micromechanical characteristics. 


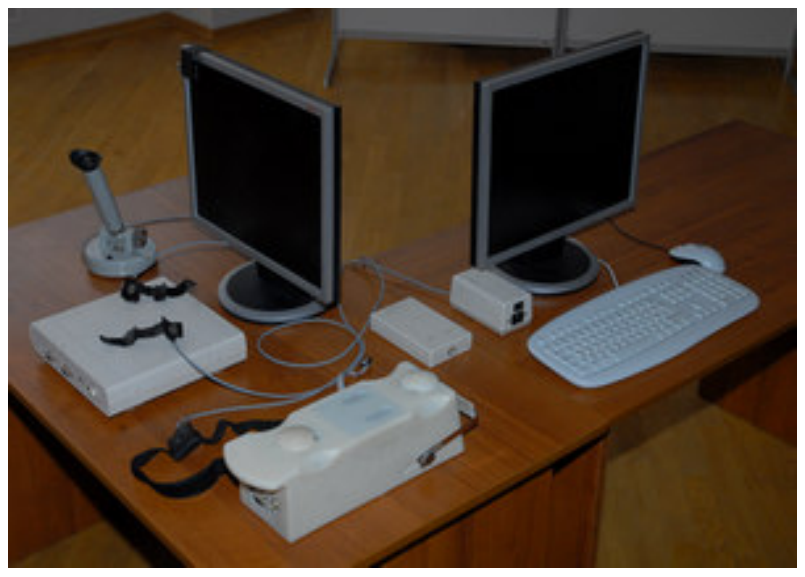

Fig 1. Multichannel computer complex
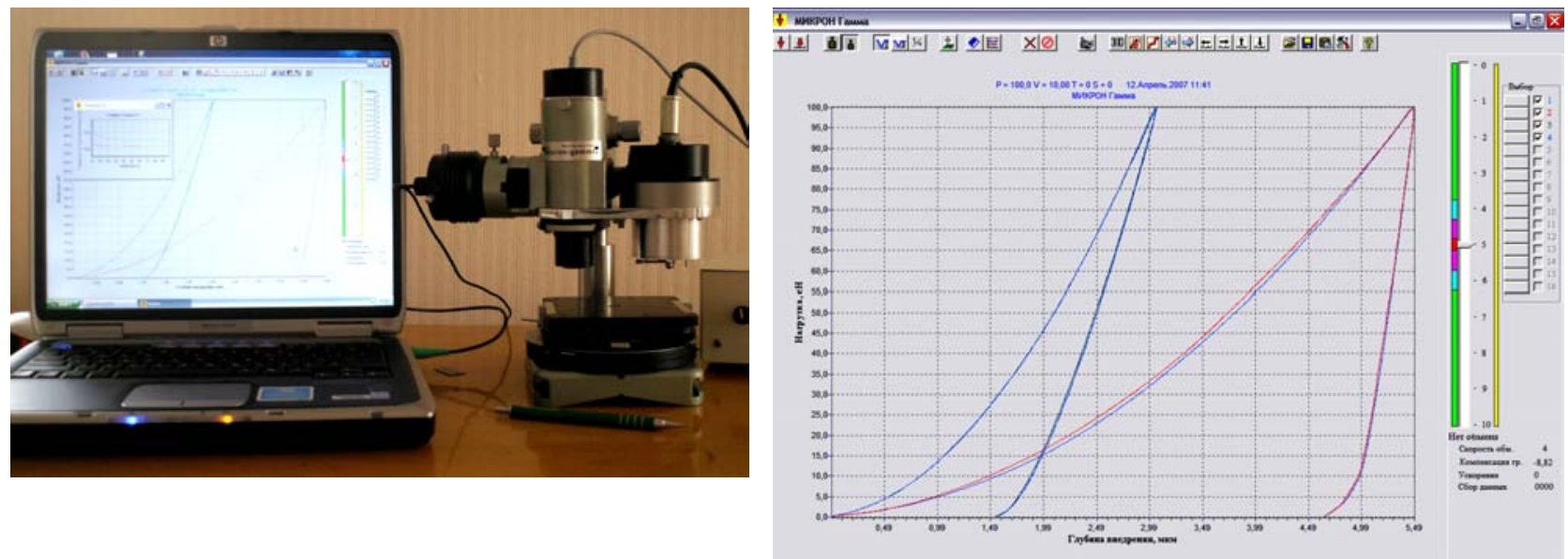

Fig 2. Micron GAMA nanotester

The TL-410M functional flight simulator was upgraded by university scientists and engineers (Figs 3, 4). This was done by means of replacing analog simulators with digital ones. Moreover, the projective digital visual conditions simulator contains a computer graphics generator. The upgraded functional flight simulator for the L-410 aircraft provides the ability to conduct training for piloting in normal and difficult conditions, training for carrying out controlled instrument approach and landing, manoeuvres at the stage of landing depending on the specific conditions of a certain airfield, etc.

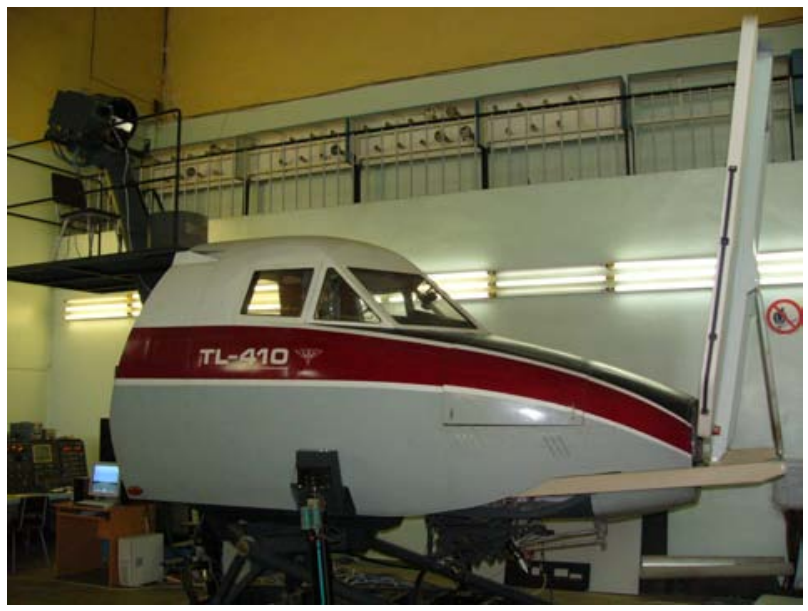

Fig 3. TL-410M functional flight simulator

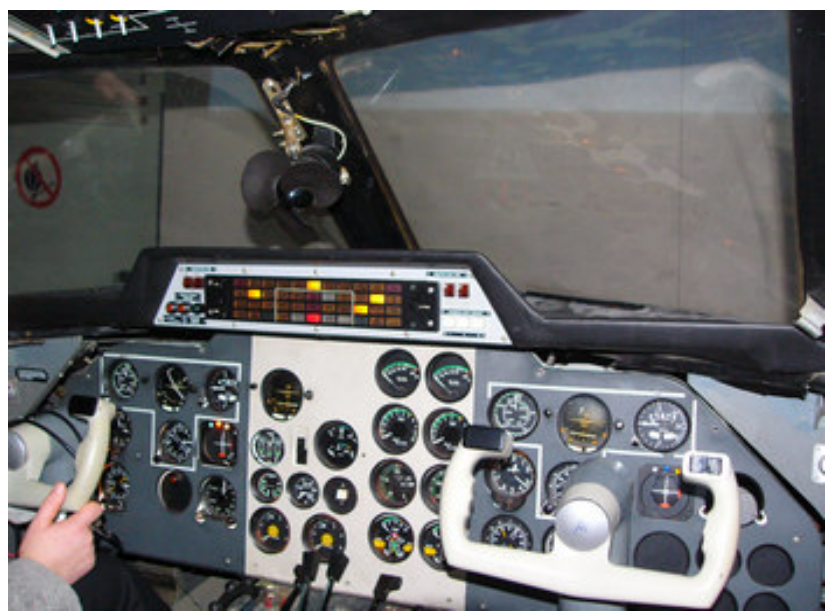

Fig 4. TL-410M functional flight simulator (interior)

An interesting achievement of the university scientists and engineers is the Sky Patrol M7, an experimental unmanned aerial vehicle (UAV) with an integrated navigation complex and real-time video surveillance systems designed and assembled with university financial support (Fig 5). 


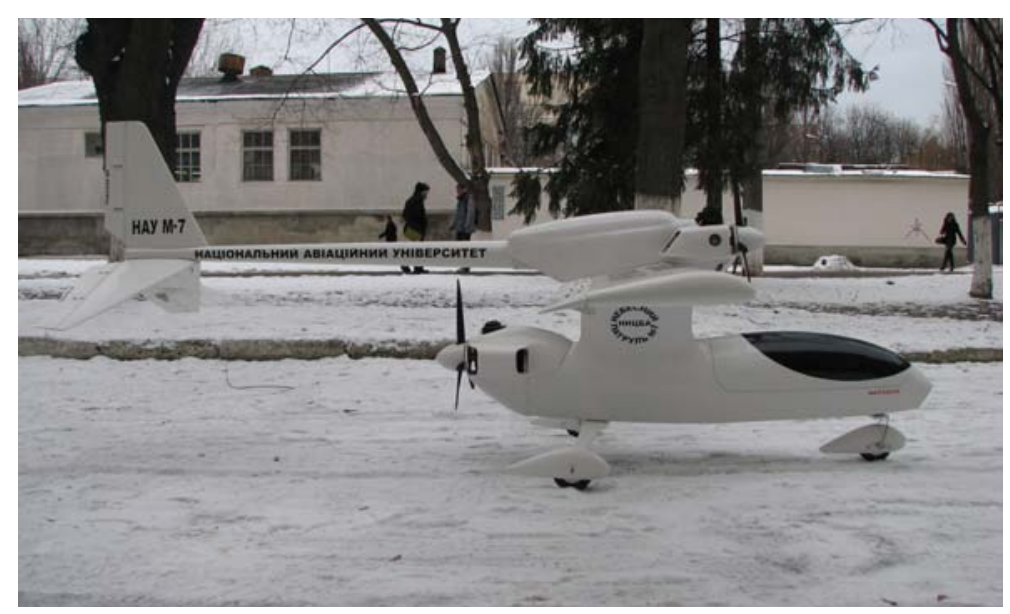

Fig 5. An experimental unmanned airplane

The unmanned twin-engine aircraft has an unusual power plant installation, various types of on-board equipment, and a microprocessor system for automatic flight control and was designed for long-term day and night observation flights.

Several university scientists were presented state awards in the fields of science and engineering for the series of scientific research devoted to aviation and space engineering protection from destructive actions and disturbing electromagnetic factors of natural and artificial origin, to information diagnostics, to technologies of reliability and aeronautical operations safety provision, to the development and implementation of innovative management, and to economics and information technologies for institutional systems in the Ukraine.

In 2008 university scientists have completed work dedicated to the development of an active aircraft protection system against guided missiles with an infrared target seeking device, in particular against portable air defence missile systems (Figs 6, 7).

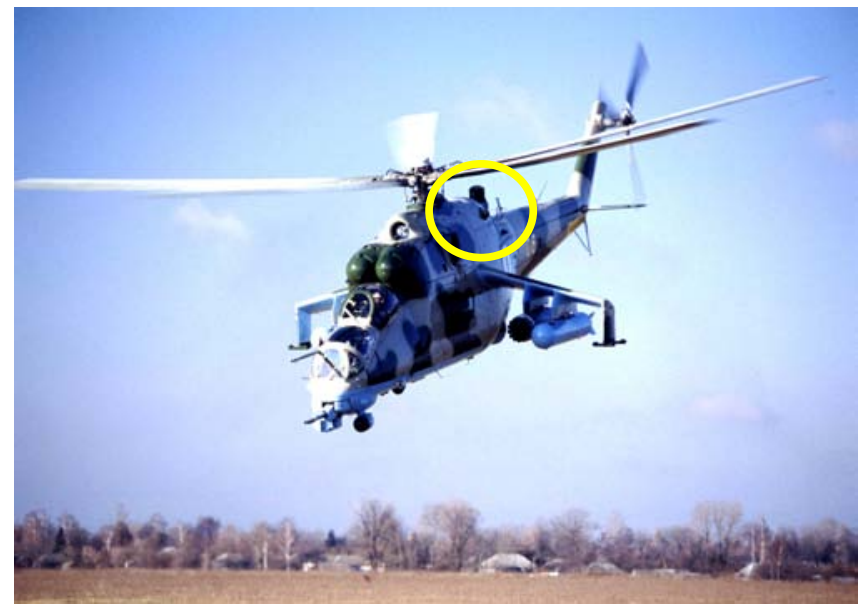

Fig 6. Active protection system on the Mi-24 helicopter

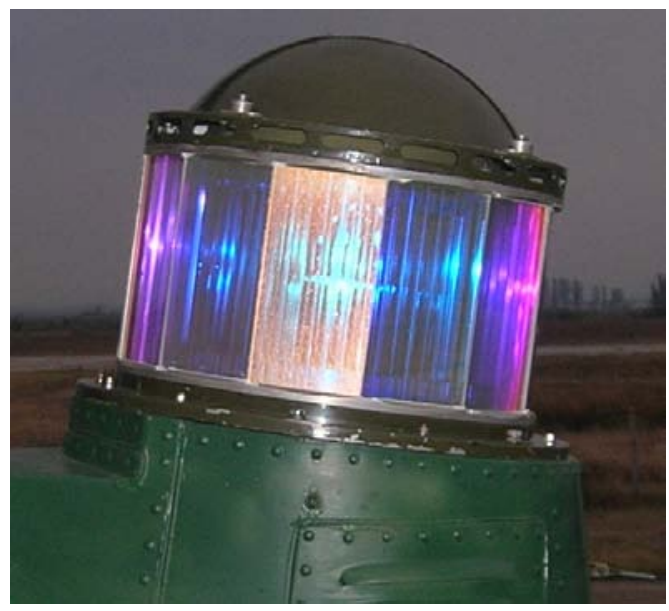

Fig 7. Adron opto-electronic suppression station

The work mentioned above was done by the National Aviation University and Adron, a scientific manufacturing company in Kiev, together with scientists of the National Academy of Defence of Ukraine. This system has successfully passed all kinds of tests and was put into service by the military forces of Ukraine.

The principle of integrating the university into the global scientific education environment was developed and is being implemented with careful regards to all the achievements and traditions gained by many generations of personnel and students.

The participation of the university in the activity of the global scientific and technical community is carried out by taking part in international programmes, and making bilateral and multilateral agreements with foreign institutions of higher education, training centres, associations, and companies. The National Aviation University cooperates with more than 100 foreign scientific and educational establishments.

Taking into consideration the upstanding role of the National Aviation University in training aviation specialists and also its human resource, scientific, material, technical and methodical potential, the ICAO Council in 1996 and 2001 made the decision to create two ICAO European Regional Training Centres at the university under the auspices of 
the ICAO institute. Acting director is Professor Galyna Suslova, who heads scientific, methodical and training work. Its activity is focussed on improving the safety level in civil aviation by means of high-quality standardized training of aviation industry personnel, who can earn international ICAO certificates, therefore promoting the importance and authority of the university in the international aviation environment.

Since 1999 the so-called English-speaking project has successfully functioned at the university. Within the framework of this project, the study process for students in 13 technical specialties is carried out in English only. For that technology for arranging the study process was developed, scientific and pedagogical staff was trained, and corresponding methodical support was done. Students from Ukraine, the CIS, and other countries study in Englishspeaking academic groups. Graduates receive a state diploma of graduates of a corresponding level of qualification and a certificate attesting to their professional level of English. Responding to the demands of the global labour market, the university has also been operating a Spanish project since 2005. Within the framework of this project, the study process is carried on only in Spanish for students of one major.

This year the National Aviation University will celebrate its $75^{\text {th }}$ anniversary. As usual, thousands of young people will enter the university in order to dedicate their lives to aviation. They will definitely carry the respectable title of graduate of the National Aviation University through their lives and will contribute to their field, remembering their time spent at the university as the best period of their lives.

The motto of the National Aviation University, which completely defines its activity, is VIVERE! VINCERE! CREARE! (Live! Create! Win!). This motto shines in the heart of every employee, student and graduate, highlighting the certain progress of the university in the future.

\section{NUOLATINĖ PLĖTRA YRA SĖKMĖS GARANTAS}

\section{Kulyk}

S a n trauka

Nacionalinis aviacijos universitetas (Ukraina) šiemet švenčia 75-sias ịkūrimo metines. Per tą laikotarpi išleista apie 150000 specialistų, kurie dirba netgi 150-yje pasaulio šalių!

Universitete didelis dèmesys skiriamas mokslinei veiklai - pastoviai kuriamos ir diegiamos progresyvios mokslinės naujovès, įvairiapusiškai bendradarbiaujama su kitų šalių aviacijos mokslo institucijomis, dalyvaujama ịvairiuose tarptautiniuose projektuose ir programose.

Nuolatinè plètra yra universiteto sèkmingos veiklos garantas. Pagrindinis devizas - VIVERE! VICERE! CREATE! (Gyvenk! Kurk! Laimèk!).

Reikšminiai žodžiai: švietimas, nuolatinè plètra, moksliniai tyrimai, tarptautiniai projektai, naujovès. 